\title{
Local Wisdom of Osing People in Conserving Water Resources
}

\author{
Sumarmi ${ }^{1 \bowtie}$ \\ ${ }^{1}$ Fakultas Ilmu Sosial Universitas Negeri Malang, Indonesia \\ Permalink/DOI: http://dx.doi.org/10.15294/komunitas.v7i1.3429 \\ Received : Feb 2015; Accepted: March 2015; Published: March 2015
}

\begin{abstract}
Each tribe in Indonesia has certain local wisdom to conserve their environment, including managing water resources. The purpose of this research is to identify the local wisdom of Osing people in conserving water resources in Kemiren, Glagah Sub-District, Banyuwangi. This research uses descriptive qualitative method. The data are taken through interview, observation and documentation. The local wisdom of Osing people in managing water resources involves knowledge, values, moral and ethics, and norms, which are applied in forms of suggestions, rules and sanctions, and also old sayings as a guideline for them to behave and act in maintaining, keeping and conserving Mbah Buyut Citi water spring. To keep a constant flow of water debit, they protect trees and plants around the spring (belik), both belik lanang and belik wadon. In maintaining this local culture, the older generations pass on the values, moral, ethics, and norms including Islamic norms (most of them are Moslem) as the guidelines on how to behave and act in practicing the traditions and instincts for respecting the environment to their family, neighbours, relatives and children-grandchildren,.
\end{abstract}

\begin{abstract}
Abstrak
Masing-masing suku di Indonesia memiliki kearifan lokal tertentu untuk melestarikan lingkungan mereka, termasuk kearifan untuk mengelola sumber daya air. Tujuan dari penelitian ini adalah untuk mengidentifikasi kearifan lokal masyarakat Osing dalam melestarikan sumber daya air di Kemiren, Kecamatan Glagah, Banyuwangi. Penelitian ini menggunakan metode deskriptif kualitatif. Data diambil melalui wawancara, observasi dan dokumentasi. Kearifan lokal masyarakat Osing dalam mengelola sumber daya air meliputi pengetahuan, nilai-nilai, moral dan etika, dan norma-norma yang diterapkan dalam bentuk saran, aturan dan sanksi, serta kata-kata bijak sebagai pedoman bagi mereka untuk bersikap dan bertindak dalam menjaga, menjaga dan melestarikan mata air Mbah Buyut Citi. Untuk menjaga aliran konstan debit air, mereka melindungi pohon-pohon dan tanaman di sekitar musim semi (belik), baik belik lanang dan wadon belik. Dalam mempertahankan budaya lokal ini, generasi tua mewariskan nilai-nilai, moral, etika, dan norma-norma termasuk norma-norma Islam (kebanyakan dari mereka adalah Muslim) sebagai pedoman tentang bagaimana bersikap dan bertindak dalam menjalankan tradisi dan naluri untuk menghormati lingkungan untuk keluarga mereka, tetangga, kerabat dan anak-cucu.
\end{abstract}

Keywords: Osing people; local wisdom; water resources conservation

How to Cite: Sumarmi, S. 2015. Local Wisdom of Osing People in Conserving Water Resources. Jurnal Komunitas, 7(1):43-51. doi:http://dx.doi.org/10.15294/komunitas.v7i1.3429

(C) 2014 Semarang State University. All rights reserved 


\section{INTRODUCTION}

This research is based on the findings previously published by Nature Climate Change revealing that moratorium policy did not contribute any impact on deforestation. The biggest deforestation in Indonesia occurred in 2012, on which Indonesia suffered a loss from approximately 840 thousand hectares of primary forest. Due to such a huge number of losses, Indonesia stands in the upper place of deforestation country than Brazil which for a long time has been in the top rank of countries with deforestation (Bahri, 2014). The high level of deforestation brings Indonesia on having several impacts, such as loss of fertile lands, expansion of critical soil areas, and crisis escalation of hygienic water in some areas (Raka, 2008).

Indonesians generally need to have high concern and awareness for keeping natural resources, including water resources, from gradual loss. As Indonesia consists of very large areas and has a variety of natural resources, people, and cultures spreading all over the islands, each place owns particular local wisdom for maintaining and preserving their environment. The local wisdoms are typically applicable in forms of ideas, values, and local views which are characterized for being advisable, prudent, and valuable. They are, hence, reckoned to be helpful for people to manage natural resources around their places.

Local knowledge widely applied by local people in order to survive in a certain area has been integrated with systems of belief, norms, and cultures, and they are expressed through the practice of culture and local myth believed by the people for very long time (Sartini, 2004). The above notion belongs to the local wisdom, or indigenous knowledge system. Such a local wisdom is regarded as a stance of responses based on human's interaction with their environment. It also becomes one of ethical customs towards environmental condition within various cycles of people's life. In this regard, the local wisdom constitutes a real model of environmental ethic implementation (Marfai, 2002).

In the following view, the local wis- dom is considered a geographical phenomenon, indicated by the existence of people and their interaction with the environment. It also stands as a part of culture, and specifically is a part of traditional knowledge system. Some important ideas of local wisdom generally include the aspects of local knowledge, folklores, religion practices, local beliefs, and also some prohibitions and suggestions. Practically, local wisdom is a form of traditional mechanism comprising of three basic dimensions - dimension of cultural potency, dimension of method and approach maintaining wisdom and prudence, and also dimension of objective and intent emphasizing on life harmony, balance, and continuity (Geriya, 2004).

Local wisdom is an overall formula of knowledge, belief, understanding or insight, and also traditional practices of ethics, which controls people's behaviors in ecological community. According to Keraf in Marfai (2012), local wisdom is associated with erudition, awareness, and cultural practices about humans, nature, and also insight of relations amongst the inhabitants of ecological community. Local wisdom, by that, is applicable and pragmatically in accordance with philosophical bases that people generally have realized.

Bintarto (Mufangati, 2004) stated that natural environment is basically comprised of physical environment such as rivers, water, lands, etc., biological environment consisting of living organism like animals, plants, and humans, and also social environment involving the aspects of sociology, spirituality, and many more. In other words, people are parts of their environment, including natural and social environments.

From the whole living creatures in earth, it is human who is the most capable to adapt to any type of environment. Human's interference towards their environment and ecosystem can somehow disrupt ecological balance. The bond of humans and their environment provides them awareness and knowledge to conserve the nature as where they live, which is all because they completely realize some changes in nature and also because they are capable of handling those 
changes certainly for the sake of their own needs (Winoto, et al., 1992). In the case of Osing people in Kemiren Village, Glagah Sub-District, Banyuwangi, it is clear that the people living there have contributed a lot in preserving the water resources.

In this globalization era, technology and science have improved rapidly, and those very much affect the environment as well. Yet, what happens then is that the benefits of technology are getting doubted since they are regarded to damage the environmental system as well as to bring unexpected disaster. Due to such happenings, it is important to ponder how humans can uphold the local wisdom to preserve the environment (Herawati, 2004). During this advanced era, another prominence to think about is that how Osing people conserve the water resources in their areas definitely through their local wisdom. By that, the water sources which still exist and benefit people's life till now can constantly fulfill people's needs in the future.

Speaking of official regulation, the wisdom of Osing people perfectly fits the Constitution of Republic Indonesia Number 7 in 2004 about Water Resources, mentioned in several chapters. In chapter 1 (18), water resource preservation is an attempt to sustain the existence and the continuity of water resources' condition, quality, and functions, and also to maintain the quality and quantity of water sufficiently for sake of fulfilling the whole needs of living things for now on and for the future time. Chapter 6 (2) states that the control of water resources mentioned in the prior verse (verse 1 ) is held by the government and/or local government with acknowledgment to the rights of regions, local regulation or system, and also some other akin rights, as long as the control supports the whole national importance and constitution.

Based on the above background, some problems put under this research are: (1) how is the local wisdom of Osing people in conserving water resources in Kemiren Village, Glagah Sub-district, Banyuwangi?; (2) How do Osing people maintain their local culture for preserving water resources in
Kemiren Village, Glagah Sub-district, Banyuwangi?.

This research also aims to: (1) identify the local wisdom of Osing people in conserving water resources in Kemiren Village, Glagah Sub-district, Banyuwangi; (2) identify the ways of Osing people in maintaining the local culture to preserve water resources in Kemiren Village, Glagah Sub-district, Banyuwangi.

\section{METHODS}

This is a descriptive qualitative research. The data are taken from literature review which is relevant to local wisdom study; especially about the local wisdom is conserving water resources in local areas, interviews, observation, and records or documentations. This qualitative research is generally to identify the local wisdom of Osing people in conserving water resources in Kemiren Village, Glagah Sub-district, Banyuwangi. It also focuses on the local wisdom of Osing people in Kemiren when they look after and preserve Mbah Buyut Cili Spring, both belik lanang and belik wadon, which are used to supply people's daily needs for living and also for agricultural irrigation. The data are examined in triangulation analysis.

\section{RESULTS AND DISCUSSION}

The local cultural wisdom of Osing people in maintaining natural environment, done by unifying the system of belief, norms, culture, and tradition, has been in people's worshipped myth for a very long time. The idea of local wisdom or the system of local cultural wisdom (Sumintarsih, 2005) exists as typical knowledge of people or certain culture that has been growing as a result of humans' interaction to their environment. The local wisdom of Osing people in preserving water resources has been carried out from time to time since long time ago. The preservation is basically to fulfill daily supplies for living, drinking, bathing, laundry, and also agricultural watering to get plentiful and fruitful harvest.

Considering that the local wisdom belongs to geographical phenomenon, exposed from the interaction of humans and 
their environment, the local wisdom conceptually is a part of culture, and specifically a part of traditional knowledge system as well. Speaking further about this, substantively, the core of local wisdom involves several aspects, such as local concept, folklore, religious rituals or ceremonies, local beliefs, and also all sorts of prohibitions and suggestions. Functionally, the local wisdom is a part of tradition comprised of three dimensions, the dimension of cultural potency, the dimension of method and approach focusing on wisdom and prudence, and also the dimension of goal and direction emphasizing on harmony, balance, and continuity (Geriya, 2004).

The local wisdom is a whole formulation of knowledge, belief, awareness or insight, and traditional practices or ethics that lead people to live appropriately in an ecological community. Besides, Keraf (2002) noted that local wisdom is basically related to knowledge, understanding, and practices of humans and nature, and also the relationship of all the inhabitants of ecological community. It is applicable and pragmatically appropriate with philosophical bases that most people believe.

Environment, in general concept, includes physical environment, such as rivers, air, lands, etc., and biotic environment, like animals, plants, and humans. Amongst all inhabitants living in any environment, humans are regarded to have the highest capability in adapting to their living places or environment. Despite probable assumption that humans' interaction to nature brings damage and disruption towards ecological balance, the bond of humans and their nature can somehow provide knowledge and ideas of how to maintain the nature and environment around humans' life. That is all because humans fully have realized any changes happening around their living places and how to deal with the problems related to those changes, which is certainly for the sake of satisfying their living needs (Winoto, et al., 1992).

Counting on the findings of this study, the local wisdom of Osing People in Kemiren in managing water resources is vividly appropriate as they get water from the closest resources (usually accommodated in stockpiles of water), from PDAM (the water is distributed from the spring/water resources to pipes of every house), and also from wells. The local wisdom of Osing people in conserving water resources through knowledge, values, ethics, morals, and norms in sorts of advice, prohibition, and sanction, and also any relevant expressions is the basis of how people there manage, maintain, and take care of all the springs or water resources, which one of them includes Mbah Buyut Cili. In addition to that, plantation around the water springs, such as in belik lanang and belik wadon, can provide benefits to the attempts of conserving water, especially to conserve the quality of water debit.

The livelihood of Osing people is mostly farming, or precisely raising crops. For that matter, water is definitely important to irrigate their farm particularly rice farms. To maintain water supply, they have to be wise and careful when managing or using water. By the time of harvest, the owners of crop usually build paglak, a two-level hut and placed close to trees, and they also craft a sort of tool like a simple drum or percussion instrument made of bamboos. As for this practice, people somehow have to obey the local regulation, in which they cannot cut down the trees as long as they want. Instead, they have to arrange a proper ritual prior to chopping down the trees.

Osing people in Banyuwangi think about their nature and living environment positively. As most people have realized, humans have to make use of the great nature, which God has freely granted to them, as best and wise as possible. The use of nature is supposed to balance humans' life and interaction to the others, including all animals and vegetation. They also believe that nature as where they live provides all benefits especially for their living needs, like irrigating their farms. They are completely aware of how they are supposed to maintain and make use of the nature appropriately, not excessively, or only when they need to use it. In regards to taking benefits from nature and the attempt to preserve the existing 
environmental wisdom, Kemiren people strongly uphold their local principle, mentioning that "the fortune of nature is not necessarily for now or for people living now as young generations also deserve the wealth". People are, hence, responsible to conserve and to take care of the nature as best as possible.

To avoid any dryness or drought, people in the village must not cut down the trees growing around the water sources. The prohibition completely comes with threat and also penalty from the local government. However, the threat is put for the sake of taking care of natural balance and harmony. It is additionally because water is one of the most important supplies that people need for daily life. In regards to this reason, Osing people also attempt to arrange a traditional ritual called Selamatan Rebo Wekasan, held in the areas around the water springs, once in a year. The ritual aims to provide an offering or serving to God or to the spirits they believe in. On the day of the ritual performing, people there are not allowed to take water from the springs or the sources.

Osing people mostly believe in a local myth that there exists a spirit that guards the water sources. They name it danyang, a spirit to whom they offer the serving during the ritual. The servings usually include some traditional food, such as jenang abang and sego golong. Again, such a belief leads them to always care and conserve the water sources with the best attempt they can and also with mutual assistance from their fellow people in the village. Another case relevant to such a belief, Osing people are certain of the existence of danyang or a sort of supernatural beings in every water source or spring. The spirits demands the people to give them regular offerings, especially when people have special affairs, such as circumcision, marriage, feast after having nadhar, etc., or, at least, people have to provide the servings once in a year, exactly on Rebo Wekasan ceremony. Besides, people are strongly prohibited to chop down the trees around belik (the water sources or springs), including belik lanang (the springs used by males) and belik wadon (the springs used by females). Then, people there cannot litter anything around the springs including not defecate or excrete on the springs. Those attempts and regulation in preserving the water sources have been going from the former descendants of Osing people to the next generations. It is all exactly for maintaining the cleanness, purity, and healthiness of water, so that people can always be sufficiently able to fulfill their needs of water.

Osing people mostly use belik lanang and belik wadon to satisfy their needs of water, such as to bath, to wash, to drink, and so forth. For the overall needs of water, the importance of water gets more obvious as most Osing people, as stated previously, work in farms. To maintain the quality and condition of water, Osing people barely miss the offerings and pageant on Rebo Wekasan ceremony. The prayers and all things presented there are specially intended for the goodness of their farms and crops. The ceremony and offering rituals are also believed as a form of gratefulness to God for giving them sufficient bless and sustenance so that the crops and farms can be well-irrigated. For the sake of preservation and continuity of plentiful daily supplies, Osing people realize that they really have to conserve and maintain the water sources very well. Good water brings them adequate fulfillment for daily needs, irrigating crops, and other necessities, which also benefit their younger generations.

In the further attempt, Osing people plant some big trees around their farms. They also build paglak, a place for them to rest after working in the farms and also for holding the ceremony or rituals of gratefulness before harvesting the crops. There are a variety of trees planted around the water sources, such as bamboo (ori and petung), bendo, kluwak, candlenut trees, coconut trees, fruit plantations, and many more.

The trees that people cannot haphazardly cut down are the ones planted close to the springs or water sources, like fig trees, and other big trees usually planted around the fields or farms (there are usually fig trees, bamboos, and durian trees planted close to paglak). The prohibitions of chopping down 
the trees are definitely intended to preserve the existence and to maintain the quality of the water sources.

\section{The Means of Osing People to Preserve Local Culture and to Conserve Water Resources}

People in Kemiren, Glagah Sub-District, Banyuwangi have been doing many attempts to preserve art and culture existing in that society. Some cultural attractions usually performed include Barongan, Nginang, Paju Gandrung, Tumpeng Sewu, Mepe Kasur, Mocopat Lontar Yusuf, and sung poetry specifically coming from Osing culture. There are a lot of cultural forms and values in Osing community, Kemiren. Besides being performed as cultural attractions during the festivals or local carnivals, the cultural practices are also represented in spiritual ceremonies. Osing people in Kemiren have a faith that Mbah Buyut Cili was the founder and the prominent elder of Kemiren village, whose graveyard is on the bank of one the farms in Kemiren and is considered sacred or sacrosanct. There usually comes a lot of visitor to the graveyard of Mbah Buyut Cili, especially on the nights right before Friday and Tuesday. People are supposed to arrange rituals on those nights in order to provide offerings to Mbah Buyut Cili; otherwise, Mbah Buyut Cili comes to every house of Osing people.

Still to conserve the local culture, as highlighted in the above points, the elders of Osing community teach their family, relatives, children, and even grandchildren to understand about the values, ethics, mo$\mathrm{ral}$, and norms, including religious norm as most people living there are Moslem. The teachings are supposed to be the bases of Osing people to behave, to have a stance, to hold the local traditions, and to naturally appreciate and maintain the nature for the sake of young generations' life.

Despite the fact that most of Osing people are Moslem, Osing people in general do not ever separate, discriminate, or differentiate their deeds from one to another when it comes to the responsibility to conserve the nature and water resources. They believe that all people have the same responsibility to not cut down the trees around the water resources in order to avoid drought and also to manage and make use of water as wise as possible.

Osing people are mostly farmers. Kebo-keboan is one of the rituals held by Banyuwangi people to ask for God' mercy and bless to bring their crops fruitful and plentiful harvest. In conducting the ritual, some people put on buffalo costume and make-up that symbolize the works of farmers to dispel plants' disease/pests, to manage crops, and also to conserve water resources along the year until the days of harvest come. Kebo-keboan has been a part of Osing people's life, internalized as a part of tradition and local wisdom in preserving environment. The theme of kebo-keboan is intentionally made for showing off the tradition of Osing people that traditional practices can fit harmoniously with today's modern life. The rituals are also passed from generations of descendants to the next generations. It is regarded to be a local specific culture of Osing society (nguri-nguri bedoyo), that even currently has become one of traditional practices to held in some important events, like Osing Cultural Festival that is annually held in that area. Interestingly, the rituals, festivals, and traditional events of Osing community can also attract domestic tourists to come and directly see the process of traditional events. Considering this benefit, the local government of Osing community intends to develop such events into the bigger and more serious performance. It is also because Banyuwangi is situated close to Bali which may allow extra package for Bali tourism and may also bring more foreign tourists to come to the area.

Such contextual rituals and events of Osing people, additionally, resemble practices of agricultural communities where most of the inhabitants are farmers. People express their gratefulness of what God has given them through the ceremonial rituals. The means or methods are not the primary point on such ceremonies or rituals; instead, it is the aim and intent that are put into the most valuable consideration and importance when conducting the rituals (Rohcsun 
dan Lestari, 2012).

There are some examples of local wisdom in the other places in Indonesian archipelago, which are similar to the attempts of Osing people, Banyuwangi, in conserving the environment: (1) Papua has a particular local belief named te aro neweak lako (nature is me). Erstberg and Grasberg Mt. are assumed to be the mother's head, while the lands are the element of humans' life. Such a belief leads people living in that culture to make use of natural resources appropriately and wisely. (2) Dayak Kenyah, East Kalimatan has tana'ulen tradition. The woods belong to local community, and are under the control of local people there. So, the management and preservation of lands are regulated by the custom law. (3) People in Kasepuhan Pance Pangawinan, Dukuh Community, West Java strongly believe in traditional ceremonies, myths, and taboos, so they make use of woods and forest really carefully without exploiting the nature unless the elders of community allow them to do so. (4) Bali and Lombok has awig-awig.

There are still many other forms of local wisdom which till presently have become people' bases or guide, like people in Jawa (pranoto mongso, Nyabuk Gunung), who consider some places sacred; in Sulawesi who control the wisdom in forms on prohibitions, suggestions and also sanctions; and in Badui Dalam who have buyut, pikukuh and dasa sila traditions. Subak, Balinese traditional practice for irrigating the agriculture, Sasi tradition in Maluku and Papua used to avoid the excessive fish catching and exploitation, zoning in Papua and $k a-$ ruhun in Sunda to manage and to maintain the use of lands/woods and water, and also leuweung in Sunda that regulates the maintenance and benefits of woods and lands, are only some other local wisdom examples which are very environmental-friendly and bring positive impacts towards people living around the areas (Suhartini, 2009).

In line with Aulia's (2010) findings of traditions in Kampung Suta, West Java, the present research also underlines some basic issues related to local culture, pamali, in the attempts to conserve water, involving some regulations like :(1) people cannot go into Hutan Keramat, but on Friday and Monday only; (2) people must not spit out, defecate or urinate in the area of Hutan Keramat; (3) people must not seize or even kill the animals living in Hutan Keramat; (4) people cannot break the twigs, branches, and also cut down the trees in Hutan Keramat; (5) a prohibition to enter Hutan Keramat without being accompanied by the guide or kuncen. Such examples of local cultural wisdom also bring some influence to the perpetuation of water resources in Kampung Kuta.

The other findings relevant to the present findings are noted in Siswadi, et.al. (2011), mentioning that : Norms are basically suggestions for: (a) keeping and taking care of the sanity of water resource environment; (b) holding ritual events, ceremonies, feast, charity, and also providing offerings to the spirit around water resource areas, intended for showing thankfulness and appreciation to tuk serco who has provided great benefits and favor to people's life; (c) fulfilling the pledge of offering tradition that is supposed to be good, plentiful and sincere; (d) letting tuk serco's condition as the way it is, without even altering it into betterment. The other norms regulating some prohibitions are: (a) people cannot wash dishes, meats, pans, and cans of fish by turning back on the spring; (b) people must not be arrogant and ignorant; (c) no litter around the spring; (d) no taking and changing the position of things placed around the spring; (d) people must not build some structures around the spring areas even if it is for urgent, semiurgent, permanent, or temporary needs; ( $f$ ) people cannot get water for irrigation from the above of spring or fountain. Also, people believe in some traditional expressions, like: (a) Urip kuwi bakal bali marang sangkan paraning dumadi, which means that all people in the world will ultimately go back to their creator, and so they have to be responsible to all of their deeds, including not to damage the nature; (b) Ning endi ono wong usil, kono ono bencana, intended to say that if there are bothersome people in particular area, there will come disasters (Siswadi, et al., 2011). 
The above findings are also highlighted in Gadgil et al.'s (1991) research, documenting that it is true that, along humans' life history, there always exists some people or community who really provide awareness to the use of natural resources, and they even have applied the right system of natural resource conservation. The practices of local wisdom for conserving natural resources are commonly based on some simple regulations but still assuring long-time uses of natural resources, which are aimed to maintain and preserve the continuity of natural resources.

Considering on the other relevant support from Burirat (2010), it is worth noting that the local wisdom in making use of woodland resources should benefit people. This is to create profitable ecological system also by building up balanced and continuous ecology. Besides, conventional policy from the Buddhist ideology provides people with personal freedom to be dependent to each other and to maintain the harmony between human to the other humans and humans to their nature.

Susilo (2013) has also documented relevant findings to the present research mentioning that the management of water resources is generally supported by people's most beneficial local wisdom. The regulation about water resources officially enables water privatization or private ownership of water to which the water should be provided for, including for those taking a lot of benefits from natural resources (look at the cases of PT. Aqua-Danone in Ponggok, Polanharjo sub-district, Klaten and also in Pati, Central Java). Due to such a policy, local people in those areas are certainly not profited. They take less water since the water resources for public community are limited and the amounts of water supplies get lessened. Unlike the cases above, people in Bumiaji, Batu, strongly decline the PDAM's policy to commercialize the water resources. Regarding the cases above, it is getting more obvious that local wisdom is definitely important and needed to preserve and maintain the water resources which are to benefit people and also to supply people's daily needs ap- propriately and sufficiently.

In the past, our ancestors once also owned the local wisdom to conserve natural environment by using their own methods, and each area had different ways of conservation attempts. Therefore, people now are responsible to explore more about such local wisdom and widely pass it to students through teaching and learning method, either directly attached in the learning steps or used in materials/media made by the teachers. That is all precisely to build students' characters and awareness to maintain and conserve environment.

\section{CONCLUSION}

To wrap up the overall discussion, the present research infers that local cultural wisdom has gone along people's living aspects and been applied since long time ago. It is conducted along with environmental conservation including water resource preservation. Therefore, the implementation of local wisdom practices by Osing people, Banyuwangi, in conserving water resources have to be continually developed through education, training, practice, cultural attraction for upholding the local culture (nguringuri budoyo) and retaining the continuity and quality of water in all water resources.

\section{REFERENCES}

Aris, M.M. 2012. Pengantar Etika Lingkungan dan Kerifan Lokal. Yogyakarta. Gadjah Mada University Press.

Aulia, T.O.S and Dharmawan, A.H. 2010. Kearifan Lokal Dalam Pengelolaan Sumber daya air di Kampung Kuta. Sodality: Jurnal Transdisiplin Sosiologi, Komunikasi, dan Ekologi Manusia, 4(3):345-355.

Bahri, S. 2014. Deforestasi Tinggi, Pemerintah Gagal Kawal Inpres no 10/2011. Dakwatuna com/ 3 Juli 2014.

Burirat, S., et al. 2010. A Study of Local Wisdom in Management of the Community Forest in Ban Nong Hua Khon, Tambon Nong Muen Than, At Samat District, Roi-Et Province. Pakistan Journal of Social Sciences, 7(2):123-128.

Gadgil, M. and Berkes, F. 1991. Traditional Resource Management System. Manila. Resource Management and Otimization

Geriya, I.W. 2004. Nilai Dasar, Nilai Instrumental dan Referensi Hukum dalam Kearifan Lokal Daerah Bali. Majalah Kerta Wicaksana. Denpasar. Fakultas Hukum Universitas Udayana. 
Herawati, I. 2004. Kearifan Lokal diLingkungan Masyarakat Using Kabupaten Banyuwangi Propinsi Jawa Timur.Yogyakarta. Balai Kajian Sejarah dan Nilai Tradisional Yogyakarta.

Keraf, S. 2002. Etika Lingkungan Hidup, Penerbit Kompas, Jakarta.

Marfai, M.A. 2012. Pengantar Etika Lingkungan dan Kerifan Lokal. Yogyakarta. Gadjah Mada University Press.

Menggali Kearipan Budaya Nusantara, (http://djatiesampoerno.weebly.com/1/post/2011/o1/menggali-kearifan-lokal-nusantara.html, browsed on 9 Desember 2013).

Mumfangati, T. 2004. Kearifan Lokal di Lingkungan Masyarakat Samin Kabupaten Blora, Propinsi Jawa Tengah. Yogyakarta. Balai Kajian Sejarah dan Nilai Tradisional Yogyakarta.

Raka, I.D.G. 2008. Pembangunan Karakter Dan Pembangunan Bangsa:Menengok Kembali Peran Perguruan Tinggi. Disampaikan pada Sidang Terbuka Majelis Guru Besar Institut Teknologi Bandung di Balai Pertemuan Ilmiah ITB, 28 November 2008.

Rochsun \& Lestari L. 2012. Studi tentang Tanggapan Masyarakat terhadap Upacara Adat Ider Bumi di Desa Kemiren Glagah Banyuwangi. Jurnal Humaniora, 9(1):6-13.

Sartini. 2004. Menggali Kearifan Lokal Nusantara Sebuah Kajian Filsafati. Jurnal Filsafat, 37(2).

Suhartini. 2009. Kajian Kearifan Lokal Masyarakat Dalam Pengelolaan Sumber daya Alam dan Lingkungan. Prosiding Seminar Nasional Penelitian, Pendidikan dan Penerapan MIPA,Fakultas MIPA, Universitas Negeri Yogyakarta, 16 Mei 2009.

Siswadi, T.T., Hartuti P. 2011. Kearifan Lokal Dalam Melestarikan Mata Air (Studi Kasus Di Desa Purwogondo, Kecamatan Boja, Kabupaten Kendal). Jurnal Ilmu Lingkungan, 9(2):63-68.

Sumaatmadja, N. 200o. Manusia Dalam Konteks Sosial Budaya dan Lingkungan Hidup. Bandung. CV. Alfabeta.

Sumarmi. 2014. Pengelolaan Lingkungan Berbasis Kearifan Lokal. Yogjakarta. Aditya Media. ISBN 978-602.7957-50-3.

Sumintarsih, et all. 2005. Kearifan Lokal di lingkungan Masyarakat Nelayan Madura.

Susilo, R.K.D. Sosiologi Lingkungan \& Sumber daya Alam perspektif Teori dan Isu-isu mutakhir. Yogyakarta. AR-RUZZMEDIA.

Undang-Undang Republik Indonesia Nomor 7 tahun 2004 Tentang Sumber daya Air.

Winoto, et al. 1992. Kearifan Tradisional Masyarakat Pedesaan Dalam Upaya Pemeliharaan Lingkungan Hidup di Daerah Riau. Jakarta. Proyek Penelitian Pengkajian dan Pembinaan Nilai-nilai Budaya Lokal. Departemen Pendidikan dan Kebudayaan. http://hamimnova. wordpress.com/2010/10/o8/nilai-nilai-pendidikan-budaya-dan-karakter-bangsa-pbkbdalam-kbm. 